\title{
The outcome of patients with advanced phase chronic myeloid leukemia with and without allogeneic hematopoietic stem cell transplantation
}

\author{
Elena V. Morozova, Yulia Yu. Vlasova, Maria V. Barabanshikova, Ksenia S. Jurovskaya, Tatyana V. Shneider, \\ Tatyana L. Gindina, Ildar M. Barkhatov, Evgenij A. Bakin, Ivan S. Moiseev, Alexander D. Kulagin, \\ Ludmila S. Zubarovskaya, Boris V. Afanasyev \\ RM Gorbacheva Research Institute of Pediatric Oncology, Hematology and Transplantation, Pavlov University, St. Petersburg, \\ Russia
}

Dr. Elena V. Morozova, RM Gorbacheva Research Institute of Pediatric Oncology, Hematology and Transplantation, Pavlov University, L.Tolstoy St. 6-8, 197022, St. Petersburg, Russia
Phone: +7(911) 9278229

E-mail: dr_morozova@mail.ru

Citation: Morozova EV, Vlasova YuY, Barabanshikova MV et al. The outcome of patients with advanced phase chronic myeloid leukemia with and without allogeneic hematopoietic stem cell transplantation. Cell Ther Transplant 2020; 9(4): 20-28.

\section{Summary}

Prognosis of patients with advanced stage CML (accelerated phase, AP, or blast crisis, BC) is still dismal in the era of tyrosine kinase inhibitors (TKIs). This study is aimed to evaluate whether allogeneic hemopoietic stem cell transplantation (allo-HSCT) improves their prognosis.

A total of 162 patients with AP/BC CML were divided into two homogeneous cohorts. The first one consisted of reduced-intensity conditioning allo-HSTC $(n=82)$ recipients. The second $(n=80)$ consisted of patients receiving only TKI-based therapy (in $85 \%$ of cases $2^{\text {nd }}$ and $3^{\text {rd }}$ generation TKIs) while not being referred to transplant center or refusing allo-HSCT. The response to therapy was defined according to ELN and NCCN recommendations.

The median follow-up for entire cohort was 44 (1-344) months. Among the patients with BC, 36 (59\%) did not respond to therapy, in 22 cases (34\%) CHR was documented, in one case ( $2 \%$ ) complete cytogenetic response (CCR) was revealed, and a complete molecular response (CMR) was achieved in two cases (3\%). Among allo-
HST recipients $86 \%$ engrafted, the $\mathrm{D}+100$ and 1 -year cumulative non-relapse mortality were $10 \%$ and $18 \%$, respectively. Twenty eight patients with post-transplant relapse received additional therapy achieving CMR in 9 cases. The 4-year OS and EFS were better in allo-HSCT compared to TKIs group: $58 \%$ vs $33 \%(\mathrm{p}=0.032)$ and $35 \%$ vs $17 \%(\mathrm{p}=0.5)$, accordingly. Patients in $\mathrm{BC}$ at the moment of allo-HSCT had significantly worse 4-year OS compared to responders: $23 \%$ vs $63 \%(\mathrm{p}=0.007)$, accordingly.

While allo-HSCT has an advantage for many advanced-stage CML patients, in $\mathrm{BC}$ its results are comparable to TKIs treatment. Therefore, these patients should be referred to transplant center as soon as the second chronic phase is achieved.

\section{Keywords}

Chronic myelogenous leukemia, BCR/ABL, allo-HSCT, tyrosine kinase inhibitors, blast crisis, outcomes. 


\section{Introduction}

The cases of chronic myeloid leukemia (CML) in acceleration phase (AP) and blast crisis (BC) are still associated with very unfavorable prognosis. Introduction of low-molecular BCR/ABL1 inhibitors into clinical practice has caused a decrease in BC incidence from $1.5-3.7 \%$ to $0.3-2.2 \%$ per year [1].

The median overall survival (OS) in untreated patients with BC CML does not exceed 3-6 months. The results of conservative treatment approach with chemotherapy and tyrosine kinase inhibitors (TKIs) are also unsatisfactory. The median OS in patients with $\mathrm{BC}$ is about 12 months [2]. According to ELN and NCCN guidelines, the evolving AP or BCs upon TKIs therapy are indications for allogeneic hemopoietic stem cell transplantation (allo-HSCT). The latter represents the only curative option for some CML patients. Starting from 2004, the cohort of allo-HSCT recipients shifted significantly from the $1^{\text {st }}$ chronic phase to TKIs non-responders and initially advanced-stage CML [3-5].

The CML evolution to $\mathrm{BC}$ is characterized by rather distinct biological features, which make it quite different from chronic phase [6]. These differences are evident not only in such characteristics as cellular proliferation, differentiation and apoptosis, but also in clinical course and therapy response rate which is associated with clonal evolution [6].

However, according to EBMT data, the long-term prognosis for patients transplanted in BC is still unfavorable [7]. The status at the time of allo-HSCT is still one of the most important prognostic factors along with donor HLA-compatibility, disease duration, and recipient's age [7].

According to the data by Khoury et al. the 3-year event-free survival (EFS) for patients transplanted in BC and AP is $8-11 \%$ and $26-27 \%$, accordingly [8]. Also, in $40 \%$ of cases patients died of disease progression.

The aim of our retrospective study was to compare two patient's cohorts receiving allo-HSCT or conservative TKI therapy in order to evaluate the therapeutic approaches that provide a survival advantage.

\section{Patients and methods}

\section{Clinical characteristics}

A total of 162 patients with CML, who had AP or BC were included in this retrospective study. All the patients included into the study were under the age of 62 years without severe cardiac, pulmonary, renal, and other comorbidities. A cohort of 82 patients received TKIs and allo-HSCT (alloHSCT+TKI) in RM Gorbacheva Research Institute, Pavlov University since 2002 to 2019 . Moreover, eighty patients received only TKIs or their combination with chemotherapy according to acute leukemia protocol, as reported elsewhere [9]. TKIs were given according to ELN recommendations [9]. The patients in TKI group did not proceed to allo-HSCT due to lack of potential stem cell donor, due to refusal for personal reasons, or delay in referral to transplant center.
The CML diagnosis was based on clinical criteria and presence of Philadelphia $(\mathrm{Ph})$ chromosome and/or chimeric BCR-ABL gene [15]. The disease stage was established according to the WHO criteria [9]. Hematological, cytogenetic and molecular responses were evaluated in compliance with ELN criteria [9]. Molecular response after allo-HSCT was evaluated according to the NCCN criteria. PCR monitoring of BCR/ABL was carried out according to NCCN recommendations once in 3 months for 2 years, then once in every 3 to 6 months. Cytogenetic investigation of bone marrow was performed according to a standard procedure with at least 20 metaphases analyzed per a sample (GTG method). The karyotype was evaluated according to International System for Human Cytogenetic Nomenclature (ISCN) [10]. In cases when the standard cytogenetic investigation was not available (insufficient material), the bone marrow was assessed by fluorescence in situ hybridization (FISH) probes aiming for detection of $(9 ; 22)$ variants (LSI BCR-ABL, Dual Color, Dual Fusion, "Vysis").

The relative BCR-ABL1 expression level was evaluated according to method described by Gabert et al [11]. The approach consists of the following stages: 1) total RNA extraction from peripheral blood of patients with CML, 2) reverse transcription with random hexameric primers, 3) real-time PCR with primers and probes specific to p210, p190 control $\mathrm{ABL}$ gene sequences. Assessment of relative expression levels is based on evaluation of $B C R-A B L 1 / A B L 1$ ratios in the studied cDNA samples. The ABL1 gene was used for normalization of the results. In order to determine copy numbers of the BCR-ABL1 and ABL1 transcripts, and to assess the reaction effectiveness, standard dilution curves were plotted using a plasmid with inserts of known target gene sequences (Invitrogen, USA), at a standard concentration ranges of $10^{2}$ $10^{6}$ copies $/ \mathrm{mcl}$, according to 2020 European LeukemiaNet (ELN) Recommendations [9] [12].

\section{Treatment options}

The conditioning regimen included fludarabine $\left(180 \mathrm{mg} / \mathrm{m}^{2}\right)$ and busulfan $(8-12 \mathrm{mg} / \mathrm{kg})$, or $140 \mathrm{mg} / \mathrm{m}^{2}$ of melphalan. Fifty-four patients $(66 \%)$ received post-transplant cyclophosphamide (PTCy)-based graft-versus-host disease (GvHD) prophylaxis. The PTCy was given at $50 \mathrm{mg} / \mathrm{kg}$ on D +3 and +4 after allo-HSCT $5 \mathrm{mg} / \mathrm{kg}$ of rabbit antithymocyte globulin $(n=3)$ in combination with tacrolimus (target concentration of $5-10 \mathrm{ng} / \mathrm{ml}$ ) from $\mathrm{D}+5$ to $\mathrm{D}+120$, and $30 \mathrm{mg} / \mathrm{kg}$ of mycophenolate mofetil (MMF) from $\mathrm{D}+5$ to $\mathrm{D}+30$, or 60 $\mathrm{mg} / \mathrm{kg}$ of horse $(\mathrm{n}=12)$, or $5 \mathrm{mg} / \mathrm{kg}$ of rabbit antithymocyte globulin $(n=3)$ in combination with tacrolimus (target concentration, $5-10 \mathrm{ng} / \mathrm{ml}$ ) from $\mathrm{D}-1$ to $\mathrm{D}+120$, and $30 \mathrm{mg} / \mathrm{kg}$ of MMF from D-1 to D+30. If allo-HSCT was performed from matched related donor, the GvHD prophylaxis consisted of tacrolimus (target concentration of 5-10 ng/ml) from D-1 to $\mathrm{D}+120,30 \mathrm{mg} / \mathrm{kg}$ of MMF rom D-1 to $\mathrm{D}+30,15 \mathrm{mg} / \mathrm{m}^{2}$ of methotrexate on $\mathrm{D}+1$, and $10 \mathrm{mg} / \mathrm{m}^{2}$ of methotrexate on $\mathrm{D}+3$ and $\mathrm{D}+6$.

The acute and chronic GvHD stage was assessed according to the common Glucksberg criteria [13], and NIH criteria [14]. The engraftment was confirmed in patients with WBC count $>1 \times 10^{9} / 1$, neutrophils of $>0.5 \times 10^{9} / 1$ without granulocyte colony stimulating factor support for 3 days, platelets count 
of $>20 \times 10^{9} / 1$ for 3 days. The primary non-engraftment was diagnosed, if no complete donor chimerism was observed on $\mathrm{D}+40$. The comorbidity index was determined according to the Hematopoietic Cell Transplantation-specific Comorbidity Index (HCT-CI) [15]. The allo-HSCT associated risk was evaluated in accordance with the Group for Blood and Marrow Transplantation Scale [7]. The immunosuppression was ceased, If there was a disease relapse, followed by donor lymphocyte infusions and/or TKIs were given as described before [16].

The TKIs were given in the post-transplant period to prevent relapses, or in cases of persistent BCR-ABL transcription as shown by PCR. TKIs were given if the neutrophil counts exceeded $0.5 \times 10^{9} / 1$, or at platelet counts of $>50 \times 10^{9} / 1$ on $\mathrm{D}+60$. The TKI choice was based on resistance pattern or history of intolerability. In $86 \%$ of cases, the patients were given $2^{\text {nd }}$ generation TKI dasatinib, since it proved to be more effective in $\mathrm{BC}$, and is able to penetrate the blood-brain barrier [17]. All the patients signed an informed consent for processing of personal data; the trial was approved by the Pavlov University Local Ethical Committee.

\section{Evaluation of results in TKI and TKI+ allo-HSCT groups}

The overall survival (OS) was estimated as a period from treatment initiation of allo-HSCT until death by any cause, or till last contact date. The event-free survival (EFS) was estimated as a period from treatment initiation of allo-HSCT until death, last contact date, or any of the following events: failure to obtain hematological response within 3 months, loss of previously achieved complete molecular response (CMR), complete cytogenetic response (CCR), or complete hematological response (CHR), post-transplant molecular relapse. Post-transplant relapse was diagnosed in case of two consecutive positive PCR assays or at least 1-log persistent increase of $\mathrm{BCR} / \mathrm{ABL}$ transcript level. If patient received a second allo-HSCT due to primary non-engraftment or a relapse, the survival terms were dated back from second alloHSCT.

\section{Statistical analysis}

The standard SPSS, IBM Statistics and R 1.41 software was used for statistical evaluation. The quantitative attributes of groups were compared using Mann-Whitney U-test. The qualitative attributes were compared by Chi-square test, Fisher's exact test. Survival charts were plotted using Kaplan-Meier method. The statistical significance of differences evaluated via Kaplan-Meier test was checked by Logrank test, the differences at $\mathrm{p}<0.05$ were considered statistically significant. The cumulative risk of non relapse-related mortality was evaluated as competing risk.

\section{Results}

A total of 162 patients with advanced CML were included into the study. In 82 cases, the allo-HSCT was performed. The remaining 80 patients received only TKIs or TKIs in combination with chemotherapy. The median follow-up was 44 (1 to 344$)$ months. There were no significant differences in gender, age, somatic status, disease phase or presence of additional chromosomal aberrations (ACAs) between alloHSCT and TKI groups (see Tab. 1). The number of patient with BC was higher in allo-HSCT group compared to TKI group, i.e., $28 \%$ versus $12 \%$. At the same time, non-transplanted patients were more likely to receive $3^{\text {rd }}$ line of TKIs than allo-HSCT group (37\% versus 18\%) as seen from Table 1 .

Table 1. Characteristics of patient groups receiving allo-HSCT or TKIs

\begin{tabular}{|c|c|c|c|}
\hline Characteristic & TKI $(n=80)$ & Allo-HSCT (n=82) & $\mathbf{p}$ \\
\hline $\begin{array}{l}\text { Gender, n (\%) } \\
\text { Male } \\
\text { Female }\end{array}$ & $\begin{array}{l}58(73) \\
22(27)\end{array}$ & $\begin{array}{l}57(70) \\
25(30)\end{array}$ & 0.55 \\
\hline Age at diagnosis, years, median (range) & $38(18-61)$ & $34(4-57)$ & 0.04 \\
\hline Age at therapy initiation/allo-HSCT, years, median (range) & $40(18-61)$ & $37(18-66)$ & 0.19 \\
\hline $\begin{array}{l}\text { Advanced phase, } n(\%) \\
\text { AP } \\
\text { BC }\end{array}$ & $\begin{array}{l}10(12) \\
70(88)\end{array}$ & $\begin{array}{l}20(24) \\
62(76)\end{array}$ & 0.07 \\
\hline $\begin{array}{l}\text { Disease phase prior to } \mathrm{HSCT}, \mathrm{n}(\%) \\
\mathrm{CP} \geq 2 \\
\mathrm{AP} \\
\mathrm{BC}\end{array}$ & NA & $\begin{array}{l}49(60) \\
23(28) \\
10(12)\end{array}$ & NA \\
\hline $\begin{array}{l}\text { Additional chromosomal aberrations, n (\%) } \\
\text { Yes } \\
\text { No }\end{array}$ & $\begin{array}{l}33(41) \\
47(59)\end{array}$ & $\begin{array}{l}35(43) \\
47(57) \\
\end{array}$ & 0.87 \\
\hline $\begin{array}{l}\text { Treatment, } \mathrm{n}(\%) \\
\text { Chemotherapy+TKI } \\
\text { TKI only } \\
\text { Chemotherapy only }\end{array}$ & $\begin{array}{l}60(86) \\
10(14) \\
0(0)\end{array}$ & $\begin{array}{l}50(61) \\
30(37) \\
2(2)\end{array}$ & 0.054 \\
\hline
\end{tabular}


CLINICAL STUDIES

\begin{tabular}{|c|c|c|c|}
\hline Characteristic & TKI $(n=80)$ & Allo-HSCT (n=82) & $p$ \\
\hline $\begin{array}{l}\text { TKI type, } n(\%) \\
\text { Imatinib } \\
\text { Dasatinib } \\
\text { Nilotinib } \\
\text { Bosutinib } \\
\text { Ponatinib }\end{array}$ & $\begin{array}{l}73 \\
61 \\
32 \\
8 \\
4\end{array}$ & $\begin{array}{l}55 \\
63 \\
29 \\
7 \\
2\end{array}$ & 0.438 \\
\hline $\begin{array}{l}\text { TKI therapy lines } \\
\text { None } \\
1^{\text {st }} \text { line } \\
2^{\text {nd }} \text { line } \\
3^{\text {rd }} \text { line } \\
4^{\text {th }} \text { line } \\
\end{array}$ & $\begin{array}{l}0(0) \\
14(18) \\
35(44) \\
30(37) \\
1(1)\end{array}$ & $\begin{array}{l}2(2) \\
22(27) \\
42(51) \\
14(18) \\
2(2)\end{array}$ & 0.019 \\
\hline $\begin{array}{l}\text { Comorbidity, n (\%) } \\
\text { Yes } \\
\text { No }\end{array}$ & $\begin{array}{l}37(46) \\
43(54)\end{array}$ & $\begin{array}{l}36(44) \\
46(56)\end{array}$ & 0.76 \\
\hline $\begin{array}{l}\text { BC type, } n(\%) \\
\text { Myeloid } \\
\text { Lymphoid } \\
\text { Mixed } \\
\text { Unknown }\end{array}$ & $\begin{array}{l}43(61) \\
17(24) \\
0(0) \\
10(15)\end{array}$ & $\begin{array}{l}26(33) \\
33(42) \\
3(4) \\
0(0)\end{array}$ & 0.001 \\
\hline $\begin{array}{l}\text { CNS involvement, } n \text { (\%) } \\
\text { Yes } \\
\text { No }\end{array}$ & $\begin{array}{l}2(2) \\
78(98) \\
\end{array}$ & $\begin{array}{l}4(5) \\
78(95) \\
\end{array}$ & 0.42 \\
\hline $\begin{array}{l}\text { Extramedullary lesions, } \mathrm{n}(\%) \\
\text { Yes } \\
\text { No }\end{array}$ & $\begin{array}{l}1 \text { (1) } \\
79 \text { (99) }\end{array}$ & $\begin{array}{l}2(2) \\
80(98)\end{array}$ & 0.57 \\
\hline $\begin{array}{l}\text { Donor, } \mathrm{n}(\%) \\
\quad \text { Unrelated } \\
\text { Related }\end{array}$ & NA & $\begin{array}{l}52(63) \\
30(37)\end{array}$ & NA \\
\hline $\begin{array}{l}\text { HLA-compatibility (out if } 10 \text { alleles), } n \text { (\%) } \\
\text { Matched } \\
\text { Mismatched } \\
\text { Haploidentical }\end{array}$ & NA & $\begin{array}{l}64(78) \\
12(14) \\
6(8)\end{array}$ & NA \\
\hline $\begin{array}{l}\text { HSC source, } n(\%) \\
\text { Bone marrow } \\
\text { Peripheral blood stem cells (PBSC) }\end{array}$ & NA & $\begin{array}{l}43(52) \\
39(48)\end{array}$ & NA \\
\hline Median CD34+ cells/kg, median (range) & NA & $4(1-18)$ & NA \\
\hline $\begin{array}{l}\text { GVHD prophylaxis, n (\%) } \\
\text { Posttransplant cyclophosphamide-based } \\
\text { Antithymocyte globuline-based } \\
\text { Methotrexate+calcineurin inhibitor }\end{array}$ & NA & $\begin{array}{l}54(66) \\
15(18) \\
13(16)\end{array}$ & NA \\
\hline $\begin{array}{l}\text { HCT-Cl value, } \mathrm{n}(\%) \\
0 \\
1 \\
2 \\
3\end{array}$ & NA & $\begin{array}{l}49(60) \\
24(30) \\
8(9) \\
1(1)\end{array}$ & NA \\
\hline $\begin{array}{c}\text { EBMT risk score value, n (\%) } \\
2 \\
3 \\
4 \\
5 \\
6 \\
7\end{array}$ & NA & $\begin{array}{l}3(4) \\
9(11) \\
25(30) \\
33(40) \\
9(11) \\
3(4)\end{array}$ & NA \\
\hline $\begin{array}{l}\text { Conditioning regimen } \\
\text { Fludarabine } 180 \mathrm{mg} / \mathrm{m}^{2} \\
\text { + busulfan } 12 \mathrm{mg} / \mathrm{kg} \\
\text { + busulfan } 10 \mathrm{mg} / \mathrm{kg} \\
\text { + busulfan } 8 \mathrm{mg} / \mathrm{kg} \\
\text { + melphalan } 140 \mathrm{mg} / \mathrm{m}^{2}\end{array}$ & & $\begin{array}{l}4(4 \%) \\
17(21 \%) \\
56(69 \%) \\
5(6 \%)\end{array}$ & \\
\hline Median CD34+ cells/kg & & $4(1-18)$ & \\
\hline
\end{tabular}




\section{Therapy and clinical response prior to allo-HSCT}

A total of 82 patients received allo-HSCT. In $48 \%$ of cases, the disease was initially in $\mathrm{CP}$, and it progressed later to more advanced stage (AC or BC). $52 \%$ of the cases had an advanced-stage disease at diagnosis. The median time span from diagnosis to allo-HSCT was $2.2(0.3-21.4)$ years. Most patients received chemotherapy in combination with TKIs, $37 \%$ of patients was administered only TKIs. All but two patients, who received allo-HSCT in 2002, had previous history of TKI treatment. Most patients (61\%) had 2 or 3 lines of TKIs, with imatinib, dasatinib or nilotinib used. Only seven patients received bosutinib and two patients received ponatinib.

\section{Patients in CP at diagnosis}

A total of 29 (74\%) of patients who were initially in CP, later developed BC. In 17 cases, a $2^{\text {nd }} \mathrm{CP}$ was achieved prior to allo-HSCT. Six patients were subjected to allo-HSCT in AP, six patients did not respond to therapy and underwent allo-HSCT in BC. In ten patients, the AP developed, and it persisted until allo-HSCT.

\section{Patients in AP at diagnosis}

A total of 20 patients had AP at diagnosis, ten of them subsequently developed blast crisis (BC). In six cases, the CP was achieved after TKI + chemotherapy $(n=4)$ or TKI treatment $(n=2)$; two patients were in AP after TKI + chemotherapy, and two patients still had BC after TKI + chemotherapy $(n=1)$ or TKI only $(n=1)$ at the moment of allo-HSCT. The remaining 10 patients had no history of $\mathrm{BC}$. Six of them subsequently achieved $\mathrm{CP}$, four patients were still in $\mathrm{AP}$ at the moment of allo-HSCT.

\section{Patients with $B C$ at diagnosis}

A total of 23 patients had BC at the time of diagnosis. In 20 cases, a subsequent chronic phase was achieved after TKI + chemotherapy $(n=17)$ or TKI therapy $(n=3)$, in one case, AP was documented after TKI therapy, and two patients were still in BC after TKI + chemotherapy $(n=2)$ at the moment of allo-HSCT.

\section{Engraftment, causes of death and non-relapse mortality}

Post-transplant engraftment was achieved in 71 (86\%) patients. The median time to WBC engraftment was 22 (8 to 39) days, median time to the neutrophil engraftment was 22 (8 to 35) days. Median time to the platelet engraftment was 19 (6 to 57) days. In 9 cases of primary non-engraftment, the $2^{\text {nd }}$ allo-HSCT was performed. The median follow-up was 35 (1 to 161) months.

Thirty-two patients died after allo-HSCT. The most common causes of death were relapse $(n=16,50 \%) ; \operatorname{GvHD}(n=8,25 \%)$; infectious complications $(n=5,16 \%)$; heart failure $(n=2,6 \%)$; hepatic veno-occlusive disease $(n=1,3 \%)$. One-year NRM was $18 \%$ (95\% CI 10-28\%), 100-day NRM 10\% (95\% CI 5-18\%), as shown in Fig. 1.

Also, 48 (58\%) patients received TKIs after allo-HSCT, 45 $(88 \%)$ of them as relapse prophylaxis. 28 patients did not

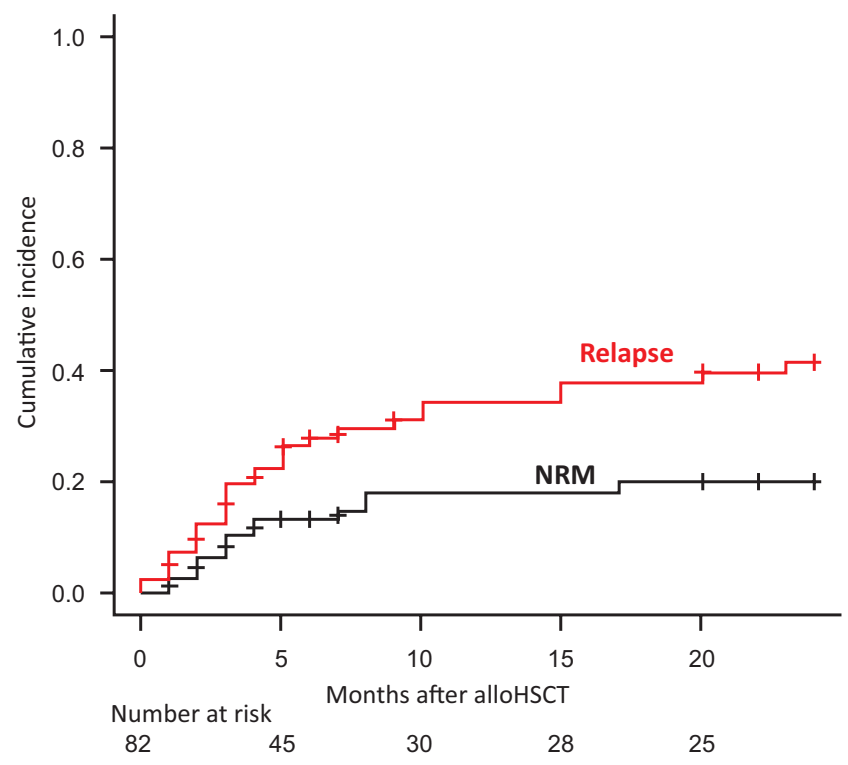

Figure 1. Cumulative 2-year relapse rate and 1-year non-relapse mortality after allo-HSCT.

Abbreviations: NRM, non-relapse mortality

develop subsequent relapses. Two patients received bosutinib, 36 dasatinib, 8 nilotinib, and 2 ponatinib.

In 31 cases (38\%), a relapse was developed, 16 of patients who relapsed received TKI prophylaxis. The cumulative relapse incidence was 39\% (95\% CI 28-51\%). In 11 patients $(34 \%)$, molecular relapse was shown; in one case, cytogenetic (3\%), and in 19 cases (63\%), hematological relapses were documented. Six patients received donor lymphocyte infusions (DLIs) for relapse treatment, five subjects received only TKIs; TKIs, chemotherapy and DLI were used in four cases; TKIs and DLIs were applied in 15 patients, and a combination of DLI and chemotherapy was used in one case. In $29 \%$ of the cases $(n=9)$, the patients had durable molecular response, in $61 \%(n=19)$, the disease progression. Evaluation of therapeutic response was impossible for $10 \%$ of the patients. DLI was performed in the remaining six 6 cases, due to primary non-engraftment or poor graft function post-transplant. In three cases, DLIs were carried out due to persisting BCR/ABL transcript.

The incidence of grade 2-4 acute GvHD was 29\% ( $n=21)$, grade 3-4 acute GvHD was registered in 20\% $(n=14)$. Chronic GvHD (cGvHD) incidence was 27\% ( $n=18)$, having been mild in 6 cases (9\%). Moderate cGvHD was observed in 8 cases $(12 \%)$, and four patients $(6 \%)$ developed severe cGvHD.

\section{Patients who received only TKls}

A cohort of 80 patients received only TKIs, or their combination with chemotherapy. The median follow-up was 93 (13-344) months. The data on outcomes was available for 71 patients. Among the patients with BC, 36 (59\%) did not respond to therapy, in 22 cases (34\%) CHR was documented, in one case $(2 \%)$ complete cytogenetic response (CCR) was revealed, and a complete molecular response (CMR) was achieved in two cases (3\%). Among 10 patients without history of $\mathrm{BC}$, one patient did not respond, 5 achieved $\mathrm{CHR}$; 
2 patients developed CCR, and CMR was registered in 2 cases. Sixty-nine patients died, more than half of them deceased due to disease progression/relapse.

\section{Comparisons between allo-HSCT+TKIs and TKIs groups}

The CML patients who received allo-HSCT exhibited significantly better 4-year OS compared to the TKI-treated group, i.e., 58\% (95\% CI 44\%-69\%) versus 33\% (95\% CI 23-44\%), accordingly ( $\mathrm{p}=0.032)$, as shown in Fig. 2A). At the same time, no statistically significant differences were found between the 4-year EFS, which was 35\% (95\% CI 24\%-47\%) in allo-HSCT, and 17\% (95\% CI 10\%-26\%) in TKIs group $(\mathrm{p}=0.5)$ (Fig. 2B). Also, there was no statistically significant difference between the 4-year OS receiving allo-HSCT in BC CML. This value was 33\% for TKIs group (95\% CI $23 \%-44 \%$ ), and $23 \%$ for allo-HSCT patients (95\% CI 3-52\%) $(\mathrm{p}=0.217)$. However, the 4 -year OS reached 63\% (95\% CI $48 \%-74 \%$ ) for the patients transplanted in AP or CP after TKIs therapy, which is significantly better compared to other groups ( $\mathrm{p}=0.005)$ (Fig. 3).

\section{A}

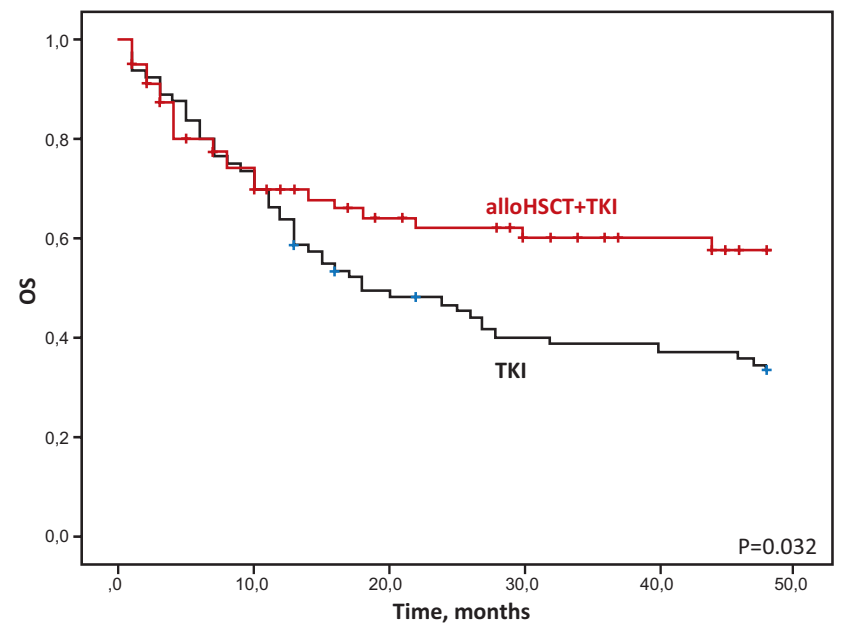

B

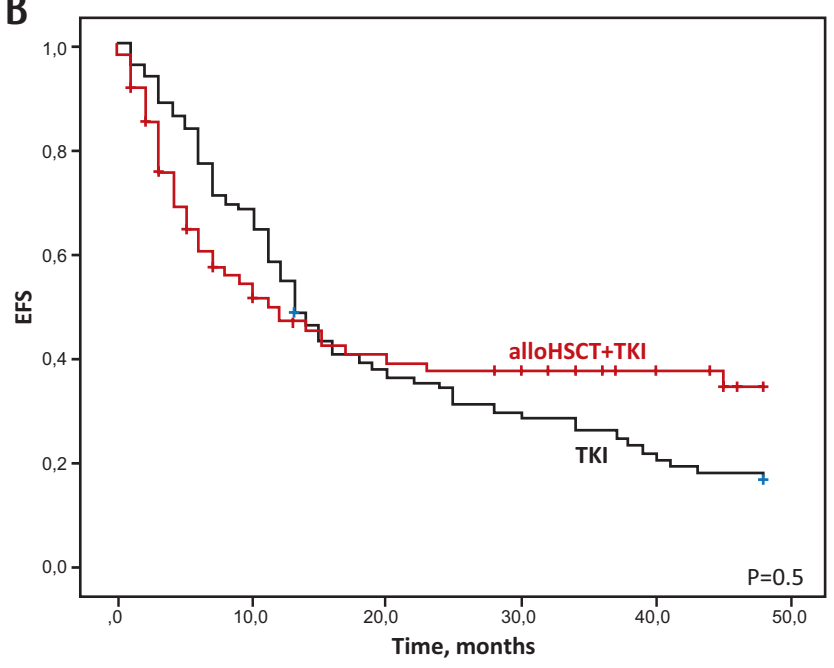

Figure 2. Four-year OS for allo-HSCT+TKIs and TKIs groups (A), and four-year EFS for allo-HSCT+TKIs and TKIs groups (B)

Abbreviations: allo-HSCT, allogeneic hematopoietic stem cell transplantation; TKI, tyrosine kinase inhibitor

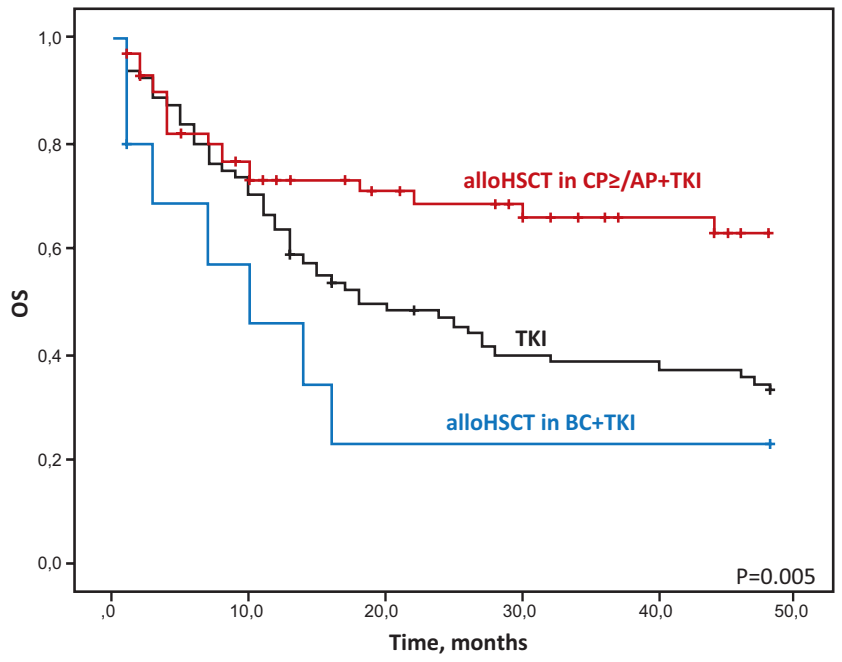

Figure 3. Four-year OS for patients treated in $B C$ who received allo-HSCT+TKIs in $\mathrm{CP} \geq 2 / \mathrm{AP}+\mathrm{TKI}$, TKIs, and allo$\mathrm{HSCT}$ in $\mathrm{BC}$

Abbreviations: allo-HSCT, allogeneic hematopoietic stem cell transplantation; $C P \geq 2$, chronic phase; $A P$, acceleration phase; TKI, therapy with tyrosine kinase inhibitors; alloHSCT in BC +TKI, allogeneic hematopoietic stem cell transplantation in blast crisis

\section{Discussion}

In our study, we compared therapy results for advanced-phase patients with CML who received TKIs with or without alloHSCT. In allo-HSCT group, the 4-year OS was significantly longer if compared to patients, who were not transplanted ( $58 \%$ versus $33 \%$, accordingly). The 4 -year EFS was also longer in allo-HSCT group ( $35 \%$ versus $17 \%$, accordingly), although without statistical significance in this case.

One should note that the relapse rate in allotransplanted patients is still as high as $39 \%$. However, CML is one of the most immunotherapy-responsive malignancies. Kolb et al. have first shown clinical success of DLIs in allo-HSCT recipients with CML [18]. Moreover, development of acute or chronic GvHD was more important for CML patients as a factor able to decrease relapse rate compared to patients with AML, MDS or plasma cell disorders [19, 20].

This may be a reason for higher OS in allo-HSCT group, while EFS rates have not differed significantly. As many relapses were sensitive to immune therapy, they were not invariably fatal, and many patients responded to post-transplant therapy. In our study, $29 \%$ of the patients achieved durable CMR upon DLI-containing treatment. However, usage of this method may be limited due to the risk of GvHD, since grade 2-4 acute GVHD develops in 15\%, and chronic GvHD occurs in $22 \%$ of patients [21]. Donor lymphocyte infusions should not be performed in patients with a history of chronic GvHD. Moreover, donor cells are not available in some cases.

Efficiency of donor lymphocyte infusions depends on many factors. The study by Basak et al. in patients with CML has shown that PBSCs as graft source worsen the long-term OS 
among DLI recipients. The authors note that there were more patients with advanced stages in PBSC group, and suppose a connection between worse DLI effect and immune response attenuation due to lower immunogenicity of malignant cells in advanced stage patients [22]. Early CML relapse is another potentially negative factor making DLIs less effective [22].

The response to DLI may depend on the type of relapse. In this study we performed DLI for 26 patients who usually presented with hematological relapses. In a study by Radujkovic et al., this method was more effective in treatment of patients with molecular or cytogenetic, but not hematologic relapses. Five-year relapse and GvHD-free survival in patients with cytogenetic and hematological relapses was $40 \%$ and $20 \%$, accordingly [22]. In our study, more than a half of relapsed patients developed hematological relapse, which may be a reason for lower response rate observed.

Prophylactic use of TKIs may exert important influence on the allo-HSCT outcomes. The relapses developed only in $38 \%$ of HSCT recipients after TKI-based prophylaxis. However, the actual role of prophylactic interventions is yet not quite clear. The largest patient cohort described by DeFilipp et al. included 89 patients [23]. The authors have not found significant differences in OS, which was $61 \%$ in recipients with post-transplant TKI prophylaxis versus $57 \%$ in the patients without such prophylaxis, and EFS was $42 \%$ versus $44 \%$, accordingly (all differences not statistically significant). Hence, the results of our retrospective study may suggest whether prophylactic TKIs improve allo-HSCT results.

Some studies have compared the results of allo-HSCT and TKIs with or without chemotherapy in advanced-stage CML patients. Worth of note, the $1^{\text {st }}$ line therapy was performed in most of these reports. In our study, however, nearly half of patients in each group received $2^{\text {nd }}$ line TKIs; $38 \%$ in TKIs and $20 \%$ in allo-HSCT+TKIs group received 3 or more lines of TKIs. Allo-HSCT was not performed, due to the lack of potential donor or failure to sign an informed consent. Therefore, the non-transplant group was more likely to receive $3^{\text {rd }}$ line TKIs than the allo-HSCT group. In study by Jiang et al., the results of TKIs with or without allo-HSCT were evaluated in 83 patients with CML BC. The allo-HSCT proved to be advantageous in 4-year OS compared to other treatment modalities, with OS of $46.7 \%$ versus $9.7 \%$, and EFS of $47.1 \%$ versus $6.7 \%$, accordingly [24]. Jiang et al. analyzed imatinib therapy results compared with allo-HSCT in 132 AP CML cases and found survival advantage for allo-HSCT compared to TKI group [25], with 5-year OS of $100 \%$ versus $18 \%$ and EFS $67 \%$ versus $9 \%$, accordingly. Jain et al. had analyzed survival rates from the moment of $\mathrm{BC}$ diagnosis in a group including 104 allo-HSCT recipients and demonstrated that allo-HSCT decreases risk of death [2].

Allo-HSCT in patients with BC lead to the same results as other treatment options, with 4 -year OS of $33 \%$ and $23 \%$ in TKIs and allo-HSCT groups, respectively. It corresponds to the published data from some other studies [24, 26, 27, 28], which makes us to recommend preferential usage of this approach in the patients with therapy-resistant disease.

Of course, the retrospective nature of our study urges us to be cautious for interpretation of its results. Meanwhile, we compared here extensive groups without showing statistically significant differences for the main clinical characteristics that could influence the CML outcomes.

\section{Conclusions}

This study has shown allo-HSCT still to be a curative method in many patients with $\mathrm{AP}$ and $\mathrm{BC}$ of CML in the presence of new-generation TKIs. However, the relapses are probable even after allo-HSCT. Due to good response to immune therapy in CML patients, a long-term remission and even curation may be achieved even after relapse of malignancy following allo-HSCT.

Tyrosine kinase inhibitors may be used as additional method for relapse therapy and prophylaxis. Performing allo-HSCT in patients with $\mathrm{BC}$ without achievement of hematological response does not lead to significantly better outcome. The indications for allo-HSCT should be discussed individually for each patient.

\section{Ackhowledgements}

No conflicts of interest reported.

\section{References}

1. Hehlmann R, Lauseker M, Saußele S, Pfirrmann M, Krause S, Kolb HJ, et al. Assessment of imatinib as first-line treatment of chronic myeloid leukemia: 10-year survival results of the randomized CML study IV and impact of nonCML determinants. Leukemia 2017;31:2398-2406.

2. Jain P, Kantarjian HM, Ghorab A, Sasaki K, Jabbour EJ, Nogueras Gonzalez G, et al. Prognostic factors and survival outcomes in patients with chronic myeloid leukemia in blast phase in the tyrosine kinase inhibitor era: Cohort study of 477 patients. Cancer 2017;123:4391-4402.

3. Bacher U, Klyuchnikov E, Zabelina T, Ottinger H, Beelen DW, Schrezenmeier $\mathrm{H}$, et al. The changing scene of allogeneic stem cell transplantation for chronic myeloid leukemia - A report from the German Registry covering the period from 1998 to 2004. Ann Hematol 2009;88:1237-1247.

4. Morozova E, Barabanshchikova M, Mamaev N, Barkhatov I, Alyanskii A, Darskaya E, et al. Chronic myeloid leukemia: Role of allogeneic hematopoietic stem cell transplantation in the era of tyrosine kinase inhibitors. Clin Oncohematology 2020;13:193-198 In Russian).

5. Saussele S, Lauseker M, Gratwohl A, Beelen DW, Bunjes D, Schwerdtfeger R, et al. Allogeneic hematopoietic stem cell transplantation (allo SCT) for chronic myeloid leukemia in the imatinib era: Evaluation of its impact within a subgroup of the randomized German CML study IV. Blood 2010;115:1880-1885.

6. Calabretta B, Perrotti D. Review in translational hematology The biology of CML blast crisis. Blood 2004;103:40104022 .

7. Gratwohl A. The EBMT risk score. Bone Marrow Transplant 2012;47:749-756. 
8. Khoury HJ, Kukreja M, Goldman JM, Wang T, Halter J, Arora M, et al. Prognostic factors for outcomes in allogeneic transplantation for CML in the imatinib era: A CIBMTR analysis. Bone Marrow Transplant 2012;47:810-816.

9. Hochhaus A, Baccarani M, Silver RT, Schiffer C, Apperley JF, Cervantes F, et al. European LeukemiaNet 2020 recommendations for treating chronic myeloid leukemia. Leukemia 2020;34:966-984.

10. Simons A, Shaffer LG, Hastings RJ. Cytogenetic Nomenclature: Changes in the ISCN 2013 Compared to the 2009 Edition. Cytogenet Genome Res 2013;141:1-6.

11. Gabert J, Beillard E, van der Velden VHJ, Bi W, Grimwade $\mathrm{D}$, Pallisgaard N, et al. Standardization and quality control studies of "real time" quantitative reverse transcriptase polymerase chain reaction of fusion gene transcripts for residual disease detection in leukemia - A Europe Against Cancer Program. Leukemia 2003;17:2318-2357.

12. Soverini S, Hochhaus A, Nicolini FE, Gruber F, Lange T, Saglio G, et al. BCR-ABL kinase domain mutation analysis in chronic myeloid leukemia patients treated with tyrosine kinase inhibitors: Recommendations from an expert panel on behalf of European LeukemiaNet. Blood 2011;118:12081215.

13. Rowlings PA, Przepiorka D, Klein JP, Gale RP, Passweg JR, Jean Henslee-Downey P, et al. IBMTR Severity index for grading acute graft-versus-host disease: retrospective comparison with Glucksberg grade. Br J Haematol. 1997;97:855864.

14. Jagasia MH, Greinix HT, Arora M, Williams KM, Wolff D, Cowen EW, et al. National Institutes of Health Consensus Development Project on Criteria for Clinical Trials in Chronic Graft-versus-Host Disease: I. The 2014 Diagnosis and Staging Working Group Report. Biol Blood Marrow Transplant 2015;21:389-401.e1.

15. Sorror ML, Maris MB, Storb R, Baron F, Sandmaier BM, Maloney DG, et al. Hematopoietic cell transplantation (HCT)-specific comorbidity index: A new tool for risk assessment before allogeneic HCT. Blood 2005;106:2912-2919.

16. Radujkovic A, Guglielmi C, Bergantini S, Iacobelli S, van Biezen A, Milojkovic D, et al. Donor lymphocyte infusions for chronic myeloid leukemia relapsing after allogeneic stem cell transplantation: May we predict graft-versus-leukemia without graft-versus-host disease? Biol Blood Marrow Transplant 2015;21:1230-1236.

17. Porkka K, Koskenvesa P, Lundán T, Rimpiläinen J, Mustjoki S, Smykla R, et al. Dasatinib crosses the blood-brain barrier and is an efficient therapy for central nervous system philadelphia chromosome positive leukemia. Blood 2008;112:1005-1012.

18. Kolb HJ, Mittermuller J, Clemm C, Holler E, Ledderose G, Brehm G, et al. Donor leukocyte transfusions for treatment of recurrent chronic myelogenous leukemia in marrow transplant patients. Blood 1990;76:2462-2465.

19. Stern M, de Wreede LC, Brand R, van Biezen A, Dreger $\mathrm{P}$, Mohty $\mathrm{M}$, et al. Impact of graft-versus-host disease on relapse after allogeneic hematopoietic stem cell transplantation, an EBMT Megafile Study. Blood 2012;120:469-469.

20. Oyekunle AA, Kröger N, Zabelina T, Ayuk F, Schieder $\mathrm{H}$, Renges $\mathrm{H}$, et al. Allogeneic stem-cell transplantation in patients with refractory acute leukemia: A long-term follow-up. Bone Marrow Transplant 2006;37:45-50.

21. Chalandon Y, Passweg JR, Guglielmi C, Iacobelli S, Apperley J, Schaap NPM, et al. Early administration of donor lymphocyte infusions upon molecular relapse after allogeneic hematopoietic stem cell transplantation for chronic myeloid leukemia: A study by the chronic malignancies working party of the EBMT. Haematologica 2014;99:1492-1498.

22. Basak GW, De Wreede LC, Van Biezen A, Wiktor-Jedrzejczak W, Halaburda K, Schmid C, et al. Donor lymphocyte infusions for the treatment of chronic myeloid leukemia relapse following peripheral blood or bone marrow stem cell transplantation. Bone Marrow Transplant 2013;48:837-842.

23. DeFilipp Z, Ancheta R, Liu Y, Hu ZH, Gale RP, Snyder $\mathrm{D}$, et al. Maintenance tyrosine kinase inhibitors following allogeneic hematopoietic stem cell transplantation for chronic myelogenous leukemia: A center for International Blood and Marrow Transplant Research Study. Biol Blood Marrow Transplant 2020;26:472-479.

24. Jiang H, Xu LP, Liu DH, Liu KY, Chen SS, Jiang B, et al. Allogeneic hematopoietic SCT in combination with tyrosine kinase inhibitor treatment compared with TKI treatment alone in CML blast crisis. Bone Marrow Transplant 2014;49:1146-1154

25. Jiang Q, Xu LP, Liu DH, Liu KY, Chen SS, Jiang B, et al. Imatinib mesylate versus allogeneic hematopoietic stem cell transplantation for patients with chronic myelogenous leukemia in the accelerated phase. Blood 2011;117:3032-3040.

26. Gratwohl A, Pfirrmann M, Zander A, Kröger N, Beelen D, Novotny J, et al. Long-term outcome of patients with newly diagnosed chronic myeloid leukemia: A randomized comparison of stem cell transplantation with drug treatment. Leukemia 2016;30:562-569.

27. Radujkovic A, Dietrich S, Blok H-J, Nagler A, Ayuk F, Finke J, et al. Allogeneic stem cell transplantation for blast crisis chronic myeloid leukemia in the era of tyrosine kinase inhibitors: A retrospective study by the EBMT Chronic Malignancies Working Party. Biol Blood Marrow Transplant 2019;25:2008-2016.

28. Hehlmann R. The new ELN Recommendations for treating CML. Early transplantation in patients with high-risk ACA. Cell Ther Transplant. 2020; 9(4): 11-19. 


\section{Клинические исходы у пациентов с хроническим миело- идным лейкозом продвинутых стадий при аллогенной трансплантации гемопоэтических стволовых клеток и без нее}

Елена В. Морозова, Юлия Ю. Власова, Мария В. Барабанщикова, Ксения С. Юровская, Татьяна В. Шнайдер, Татьяна Л. Гиндина, Ильдар М. Бархатов, Евгений А. Бакин, Иван С. Моисеев, Александр Д. Кулагин, Людмила С. Зубаровская, Борис В. Афанасьев

НИИ детской онкологии, гематологии и трансплантологии им. Р. М. Горбачевой, Первый Санкт-Петербургский государственный медицинский университет им. акад. И. П. Павлова, Санкт-Петербург, Россия

\section{Резюме}

\section{Введение}

Клинический прогноз у пациентов с хроническим миелоидным лейкозом (ХМЛ) в развернутой стадии (фаза акселерации - ФА, или бластный криз - БК) все еще остается неблагоприятным в эру применения ингибиторов тирозинкиназ (ИТК). Данное исследование проводилось, чтобы оценить, насколько аллогенная трансплантация гемопоэтических клеток (алло-ТГСК) улучшает их прогноз.

\section{Пациенты и методы}

Общая группа из 162 пациентов с ХМЛ в ФА/БК была разделена на две гомогенные когорты. Первая из них состояла из реципиентов, получавших кондиционирование со сниженной интенсивностью перед алло-ТГСК $(\mathrm{n}=82)$. Вторая группа $(\mathrm{n}=80)$ включала пациентов, получавших только терапию на базе ИТК (в 85\% случаев - препараты 2-го и 3-го поколения), не направленных в центры трансплантации или отказавшихся от нее. Ответ на терапию определяли в соответствии с рекомендациями ELN и NCCN.

\section{Результаты}

Медиана сроков наблюдения для всей когорты составляла 44 (1-344) мес. Среди пациентов с БК 36 больных (59\%) не отвечали на лечение, в 22 случаях (34\%) была установлена полная гематологическая ремиссия (CHR), в одном случае (2\%) - полная цитогенетическая ремиссия, и полный молекулярный ответ (ПМО) был достигнут в 2 случаях (3\%). Среди реципиентов алло-ТГСК, приживление отмечено в 86\% случаев. Кумулятивная безрецидивная смертность на $\mathrm{D}+100$ и через 1 год составила, соответственно, $10 \%$ и $18 \%$. У 28 пациентов с посттрансплантационным рецидивом проведена дополнительная терапия, и достигнут ПМО в 9 случаях. Общая 4-летняя выживаемость и бессобытийная выживаемость (OB) были лучше после алло-ТГСК по сравнению с группой, леченой ИТК: 58\% против 33\% (p=0,032) и 35\% против $17 \%(\mathrm{p}=0,5)$, соответственно. Пациенты в БК на момент ТГСК имели значительно более низкие уровни 3-летней ОВ по сравнению с больными, ответившими на лечение: $23 \%$ против $63 \%(\mathrm{p}=0,007)$, соответственно.

\section{Заключение}

Хотя алло-ТГСК имеет преимущество у многих больных ХМЛ в развернутых стадиях, результаты ее применения при БК сравнимы с лечением ИТК. Поэтому данные пациенты должны направляться в центры трансплантации по мере достижения ими второй хронической фазы заболевания.

\section{Ключевые слова}

Хронический миелоидный лейкоз, BCR/ABL, аллогенная трансплантация гемопоэтических стволовых клеток, ингибиторы тирозинкиназы, бластный криз, исходы заболевания. 